\title{
New combinations for two coronate polyp species (Atorellidae and Nausithoidae, Coronatae, Scyphozoa, Cnidaria)
}

\author{
André Carrara Morandini ${ }^{1}$ and Gerhard Jarms ${ }^{2}$ \\ ${ }^{1}$ Departamento de Zoologia, Instituto de Biociências, Universidade de São Paulo, C.P. 11461, São Paulo, \\ 05422-970, SP, Brazil (e-mail: acmorand@usp.br); ${ }^{2}$ Biozentrum Grindel und Zoologisches Museum, Universität \\ Hamburg, Martin-Luther-King Platz 3, 20146 Hamburg, Germany
}

Keywords: Atorella, Nausithoe, polyp, scyphistoma, Stephanoscyphistoma, Stephanoscyphus, systematics, taxonomy

\begin{abstract}
Within the order Coronatae, six valid species remain known only by their polyp stage. The inability to relate them to any medusae genera of the group is a problem that remains to be solved in the order. With the examination of type specimens, we reassign the species Stephanoscyphistoma sibogae and S. striatus to the genera Atorella and Nausithoe respectively.
\end{abstract}

\section{Contents}

Introduction 117

Material and Methods 117

Results and Discussion 118

Systematic accounts: new combinations ............................... 118

General comments and Conclusions ………….......................... 122

Acknowledgements ........................................................ 122

References

123

\section{Introduction}

The order Coronatae Vanhöffen, 1892 is considered a monophyletic group defined by the presence of a coronal furrow on the exumbrella, and the so-called pedalia of the medusae (which are radial thickenings of the jelly on the peripheral zone of the exumbrella between the coronal groove and the base of the marginal lappets) (Russell, 1970: 27; Cornelius, 1997: 120). But the most remarkable character of the coronates (and unique among the scyphozoans) is the two-layered periderm tube of their polyp stage (stephanoscyphistoma), which displays external sculpturing and internal cusps (Chapman and Werner, 1972).

An historical review of coronate medusa and their systematics is provided by Thiel (1936), and the knowledge of the polyp stage was reviewed by Jarms (1997). Research in the 1960s and 1970s showed that the so-called 'Stephanoscyphus' polyps produce medusae of the genera Atorella Vanhöffen, 1902, Linuche Eschscholtz, 1829 and Nausithoe Kölliker, 1853 (Werner, 1967; 1971; 1974; 1979). Based on the fact that 'Stephanoscyphus' polyps give rise to medusae referable to at least three other genera, and supported on recommendation of the ICZN (ICZN, 1999; Kraus, 2000), Jarms (1990, 1991) proposed the generic name Stephanoscyphistoma to accommodate species whose familial or generic assignment is uncertain, as in preserved polyps or old and inadequate descriptions.

The so far valid coronate species that remained known only by their polyp stages are: $S$. allmani (Kirkpatrick, 1890), S. bianconis (Thiel, 1936), S. corniformis (Komai, 1936), S. sibogae (Leloup, 1937), S. simplex (Kirkpatrick, 1890), S. striatus (Vanhöffen, 1910).

In the present paper we focus on the solitary coronate species $S$. sibogae and $S$. striatus, and propose new combinations for both.

\section{Material and Methods}

Observations reported here are based on reviews of original literature, and on examinations of preserved specimens of stephanoscyphistomae from the collections of the Museum für Naturkunde der Humboldt-Universität zu Berlin (ZMB), Berlin, Germany, and of the Zoological Museum, University of Amster- 
dam (ZMA), Amsterdam, The Netherlands. Measurements and scanning electron microscopy (SEM) preparations followed the procedures of Jarms et al. (2002a, b).

\section{Results and Discussion}

Tube characters: state of knowledge

Kramp (1951: 124; 1959: 174) opined that the internal processes (cusps) and the external morphology of the tubes "do not seem to be of specific importance". However, Naumov (1959) stated that the structure and arrangement of the cusps are very constant and may serve to distinguish different species. Nowadays, we are able to distinguish several species, and at least four different genera in three families of coronates, using characters of the periderm tube (see Jarms, 1991; Jarms et al., 2002a). Useful characters for identification at the species-, genus-, and family-group levels include the outer structure of the tube, the number and shape of internal cusps, the outline of the insertion of the internal cusps at the tube wall, and the shape of the exoskeleton described by the Formquotient - namely the ratio between the diameter of the tube opening and the total length (see the chapter "Protocols" in Jarms et al., 2002b). Atorellidae Vanhöffen, 1902 always have solitary polyps with cusps inserted with an outline broader than high, at least in the basal whorls of cusps. Conversely, in both solitary and colonial species of the Nausithoidae Haeckel, 1880, the insertions are higher than broad, and sometimes shaped like a vertical 8 or a cup. The colonial polyps of Linuchidae Haeckel, 1880 are characterized by being nearly isodiametric.

\section{Systematic account: new combinations}

Atorella sibogae (Leloup, 1937) comb. nov. Figs 1-4, Tabs 1-2.

\footnotetext{
Stephanoscyphus sibogae Leloup, 1937: 67 (description), 69 (key), fig. 43. Kramp, 1951: 124-125 (brief description). Kramp, 1959: 173 (mention), 180 (mention), 182 (mention). Stephanoscyphus simplex: Kramp, 1959: 174 (mention) [in part]. Stephanoscyphistoma sibogae: Jarms 1990: 11 (mention). non Stephanoscyphus simplex Kirkpatrick, 1890: 14.
}

Description of the lectotype. ZMA Coel. 2083 (Fig. 1). Solitary polyp (6.4 $\mathrm{mm}$ long), with light brown periderm tube, and small basal disc for attachment $(0.56 \mathrm{~mm})$. Formquotient at $2 \mathrm{~mm}$ height 0.2 , at 5 $\mathrm{mm}$ height 0.14 , and at the aperture 0.14 . Tube surface with a pattern of transverse rings (5-7 rings/0.4 $\mathrm{mm}$ ) with longitudinal striations, characteristic of Atorellidae. The tube has 7 whorls of internal cusps. The cusps are arranged in whorls of eight (four large perradial, and 4 smaller interradial ones). The outline of the internal cusps is broader than high.

We were unable to distinguish between the syntypes the type specimen figured by Leloup (1937, fig. 43 B') (Fig. 2), thus we designated a lectotype from them.

Description. Solitary polyps (0.3-5.6 $\mathrm{mm}$ long), with light brown periderm tube, and small basal disc for attachment $(0.3-0.54 \mathrm{~mm}, \mathrm{n}=27)$. Formquotient at $2 \mathrm{~mm}$ height $0.16-0.25(\mathrm{n}=10)$, at $5 \mathrm{~mm}$ height 0.14 $0.196(\mathrm{n}=2)$, and at the aperture $0.135-0.216(\mathrm{n}=$ 11). Tube surface with pattern of transverse rings (7-8 rings $/ 0.4 \mathrm{~mm}$ ), with longitudinal striations, characteristic of Atorellidae. The tubes have 3-6 whorls of internal cusps $(\mathrm{n}=11)$. The cusps are arranged in whorls of eight (four large perradial, and 4 smaller interradial ones). SEM preparations of the internal whorls of cusps show that the 8 cusps present secondary teeth on their surface (Figs 2 and 3). The outline of the internal cusps is broader than high. The measurements of the tubes are shown in Tab. 1.

Paralectotypes. ZMA Coel. 8969 [29 specimens, several tubes broken just above the basal disc, two taken out for SEM (ZMA Coel 2083A, 2083B)].

Type locality: Malayan Archipelago, north of Sumbawa, $794 \mathrm{~m}$ depth.

Collected by the "Siboga Expedition" on 06.iv. 1899.

Comments. The original description and illustrations (fig. 43) of Stephanoscyphus sibogae by Leloup (1937) suggest that the species is referable to the genus Atorella. The attachment outlines of the internal cusps are oval, with their width greater than their height (Fig. 2). An examination of the syntypes of $S$. sibogae confirmed this observation. The syntype series contained 30 solitary periderm tubes, one was designated as a lectotype, and two were cut and ex- 

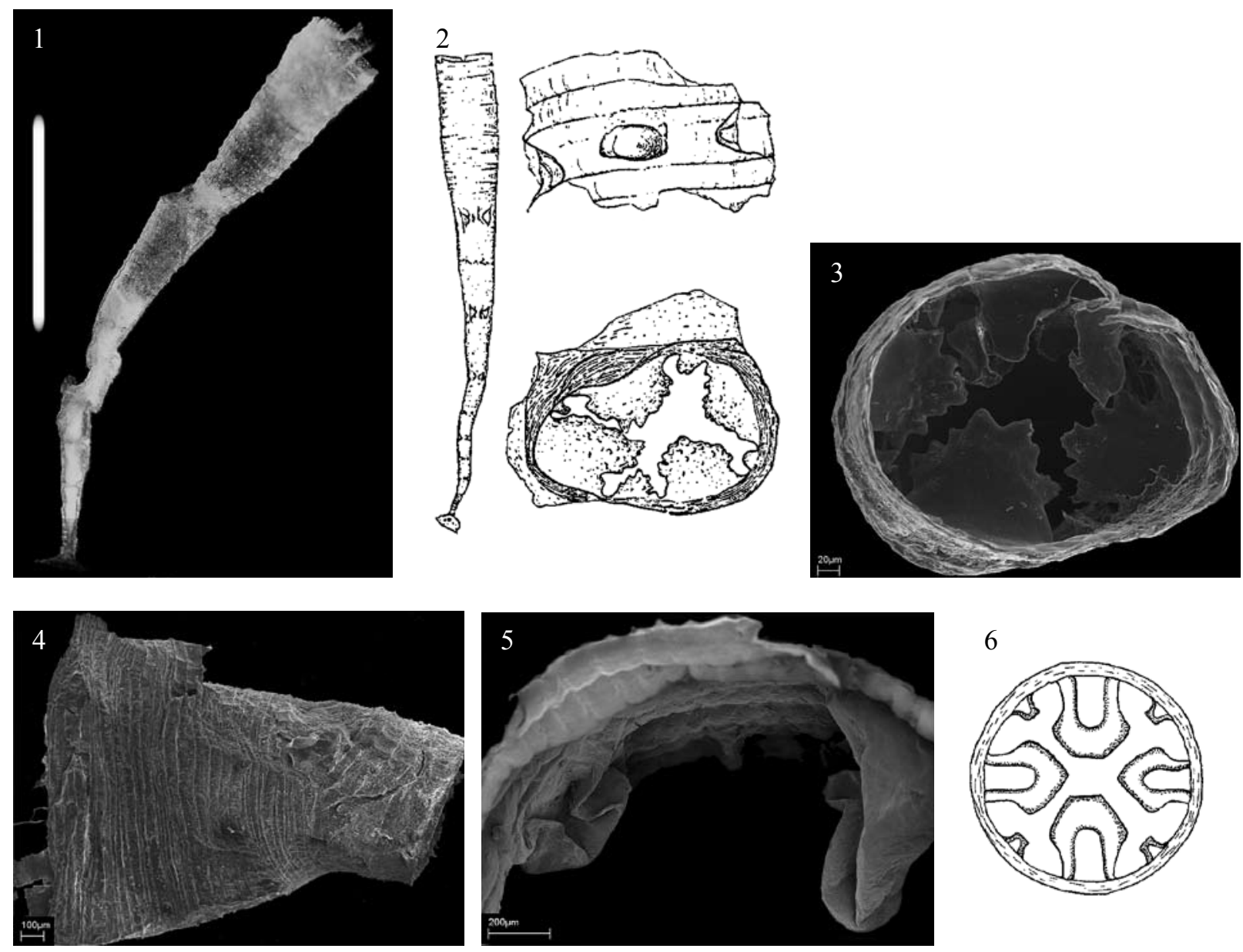

Fig. 1. Atorella sibogae (Leloup, 1937) comb. nov., lectotype (ZMA Coel. 2083). Scale $=2 \mathrm{~mm}$.

Fig. 2. Atorella sibogae (Leloup, 1937) comb. nov., reproduced from the original (Leloup, 1937, fig. 43B', C, C').

Fig. 3. Atorella sibogae (Leloup, 1937) comb. nov. (ZMA Coel. 2083A), scanning electron micrograph of one of the whorls of internal cusps. Note the presence of secondary teeth on the surface of the 8 large ones.

Fig. 4. Atorella sibogae (Leloup, 1937) comb. nov. (ZMA Coel. 2083A), scanning electron micrograph of the outer surface of the tube. Note the presence of numerous rings.

Fig. 5. Atorella vanhoeffeni Bigelow, 1909 (ZMH C 10863), scanning electron micrograph of one whorl of internal cusps. Although the cusps are shrank, the margin of them is relatively smooth.

Fig. 6. Atorella japonica Kawaguti and Matsuno, 1981, redrawn from the original (Kawaguti and Matsuno, 1981, fig. 4).

amined by SEM, and the morphology of the internal cusps was analysed.

The outer structure of the periderm tubes (Figs 1 and 4) clearly indicates that the species should be referred to the genus Atorella Vanhöffen, 1902.

Comparative data on the 3 species of the genus Atorella with known polyp stage are presented in Tab. 2. Based on the general morphology of the polyps it is not possible to separate $S$. sibogae from other Atorella species, but the morphology of the internal cusps and the presence of secondary teeth on their surface are unique among the Atorella polyps (see Figs 5 and 6). In the genus Nausithoe the presence of secondary teeth on the cusps surface is a distinguishing and unique character of the species Nausithoe werneri (Jarms, 1990, 1991).

From these results, we conclude that $S$. sibogae has to be grouped in the family Atorellidae and within the genus Atorella, and has to be referred to as Atorella sibogae comb. nov., due to the different morphology of the internal cusps.

The family Atorellidae includes six species: 
Table 1. Measurements of specimens of Atorella sibogae (Leloup, 1937) comb. nov. (ZMA Coel. 2083, 2083A, 2083B, 8969). Symbols: "." = no measurement; Dbd = diameter of the basal disc (in $\mathrm{mm}) ; \mathrm{Db}=$ diameter just above the basal disc (in mm); Do = diameter of the distal aperture (in $\mathrm{mm}$ ); Ltot $=$ total length (in $\mathrm{mm}$ ); D/L $2 \mathrm{~mm}=$ diameter at $2 \mathrm{~mm}$ divided by $2 ; \mathrm{D} / \mathrm{L}_{5 \mathrm{~mm}}=$ diameter at $5 \mathrm{~mm}$ divided by $5 ; \mathrm{Nwt}=$ total number of whorls of cusps; nwt $5 \mathrm{~mm}=$ number of whorls of cusps in the basal $5 \mathrm{~mm}$; cusps $/$ whorl = number of cusps per whorl; Formquotient $=$ ratio between the diameter of the distal aperture (Do) and the total length (Ltot).

\begin{tabular}{|c|c|c|c|c|c|c|c|c|c|c|}
\hline Specimen & Dbd & $\mathrm{Db}$ & Do & Ltot & $\mathrm{D} / \mathrm{L}_{2 \mathrm{~mm}}$ & $\mathrm{D} / \mathrm{L}_{5 \mathrm{~mm}}$ & Nwt & nwt $_{5 \mathrm{~mm}}$ & cusps/whorl & Formquotient \\
\hline ZMA Coel. 2083 & 0.56 & 0.12 & 0.9 & 6.4 & 0.2 & 0.14 & 7 & 6 & 8 & 0.14 \\
\hline ZMA Coel. 2083A & 0.54 & 0.12 & 0.62 & 4.28 & 0.22 & - & 4 & 4 & 8 & 0.144 \\
\hline ZMA Coel. 2083B & 0.5 & 0.14 & 1.2 & 5.6 & 0.25 & 0.196 & 5 & 5 & 8 & 0.214 \\
\hline ZMA Coel. 8969 & 0.5 & 0.1 & 0.8 & 5.26 & 0.2 & 0.14 & 5 & 5 & 8 & 0.152 \\
\hline ZMA Coel. 8969 & 0.4 & 0.08 & 0.56 & 4.9 & 0.22 & - & 4 & 4 & 8 & 0.114 \\
\hline ZMA Coel. 8969 & 0.3 & 0.1 & 0.8 & 3.8 & 0.2 & - & 6 & 6 & 8 & 0.21 \\
\hline ZMA Coel. 8969 & - & 0.1 & 0.7 & 3.8 & 0.24 & - & 4 & 4 & 8 & 0.184 \\
\hline ZMA Coel. 8969 & 0.5 & 0.1 & 0.6 & 3.8 & 0.21 & - & 4 & 4 & 8 & 0.157 \\
\hline ZMA Coel. 8969 & 0.4 & 0.1 & 0.5 & 3.7 & 0.17 & & 4 & 4 & 8 & 0.135 \\
\hline ZMA Coel. 8969 & - & 0.1 & 0.4 & 2.72 & 0.16 & - & 3 & 3 & 8 & 0.147 \\
\hline ZMA Coel. 8969 & 0.34 & 0.1 & 0.42 & 2 & 0.21 & - & 4 & 4 & 8 & 0.21 \\
\hline ZMA Coel. 8969 & 0.44 & 0.1 & 0.58 & 2.68 & 0.24 & - & 6 & 6 & 8 & 0.216 \\
\hline ZMA Coel. 8969 small & $0.32-0.6$ & $0.08-0.12$ & $0.1-0.38$ & $0.3-1.3$ & - & - & $1-3$ & $1-3$ & 8 & $0.2-0.538$ \\
\hline Mean $(n=30)$ & 0.425 & 0.103 & 0.435 & 2.11 & - & - & 3.2 & 3.2 & 8 & 0.265 \\
\hline Mean $>2$ mm $(n=12)$ & 0.448 & 0.105 & 0.673 & 4.07 & 0.21 & - & 4.6 & 4.6 & 8 & 0.168 \\
\hline Mean $>2_{\mathrm{mm}},<5_{\mathrm{mm}}(\mathrm{n}=9)$ & 0.417 & 0.1 & 0.575 & 3.52 & 0.208 & - & 4.6 & 4.6 & 8 & 0.168 \\
\hline Mean $>5_{m m}(n=3)$ & 0.52 & 0.12 & 0.966 & 5.75 & 0.216 & 0.159 & 5 & 5 & 8 & 0.168 \\
\hline
\end{tabular}

Table 2. Comparative table with the measurements of different species of the genus Atorella Vanhöffen, 1902 with known polyp stages (A. japonica, A. sibogae comb. nov. and A. vanhoeffeni). For definitions of symbols, see Tab. 1, As = Atorella sibogae; “*” = secondary teeth on cusps. Data from Werner (1967) and Kawaguti and Matsuno (1981).

\begin{tabular}{llllll}
\hline Species & Do & Ltot & Formquotient & cusps/whorl & Occurrence \\
\hline As ZMA Coel 2083 & 0.9 & 6.4 & 0.14 & $8^{*}$ & Malayan Archipelago \\
As mean $>2 \mathrm{~mm},<5_{\mathrm{mm}}(\mathrm{n}=9)$ & 0.575 & 3.52 & 0.168 & & \\
As mean $>5 \mathrm{~mm}(\mathrm{n}=3)$ & 0.966 & 5.75 & 0.168 & & \\
Atorella japonica & $0.2-2$ & $3-18$ & 0.13 & 8 & Japan \\
Atorella vanhoeffeni & $1.4-2.1$ & $8-15$ & 0.16 & 8 & Indian Ocean \\
\hline
\end{tabular}

A. arcturi Bigelow, 1928 (medusa: Coco Island, Indian Ocean); A. japonica Kawaguti and Matsuno, 1981 (polyp: Japan Sea, Pacific Ocean); A. octogonos Mills, Larson and Youngbluth, 1987 (medusa: Bahamas, Atlantic Ocean); A. sibogae (Leloup, 1937) comb. nov. (polyp: Malayan Archipelago, Indian Ocean); A. subglobosa Vanhöffen, 1902 (medusa: Eastern Africa and Malayan Archipelago, Indian Ocean; West of Canary Islands, Atlantic Ocean); and A. vanhoeffeni Bigelow, 1909 (medusa: off Panama, Pacific Ocean; polyp: Indian Ocean).

The diagnosis of the family Atorellidae is: Coronatae medusae with six rhopalia; solitary polyps (Stephanoscyphistoma-like) with external sculpturing with transversal rings close to each other; outline of cusps from outside broader than high. The diagnosis of the genus Atorella is: Atorellidae medusae with six tentacles; twelve marginal lappets; mouth with four lips; four, six or eight gonads; solitary Atorellidae polyps with 8 internal cusps.

Nausithoe striata (Vanhöffen, 1910) comb. nov. Figs 7-9, Tab. 3

Tubularia striata Vanhöffen, 1910: 280 (description), fig. 6. Kramp, 1959: 181 (mention).

Scyphistoma striatum: Vanhöffen, 1910: vii (mention).

? Scyphistoma striatum: Stechow, 1925: 391 (list mention), 518 (brief description), 546 (index mention).

Stephanoscyphus striatus: Leloup, 1937: 64 (description), 69 (key) [in part]. Kramp, 1951: 125 (brief description, doubt if it is a synonym of $S$. simplex). Kramp, 1959: 173 (mention). Stephanoscyphus simplex: Kramp, 1951: 123 [in part]. Kramp, 1959: 174 [in part]. Werner, 1973: 37.

Stephanoscyphistoma striatus: Jarms, 1990: 11 (mention). non Stephanoscyphus simplex Kirkpatrick, 1890: 14. 

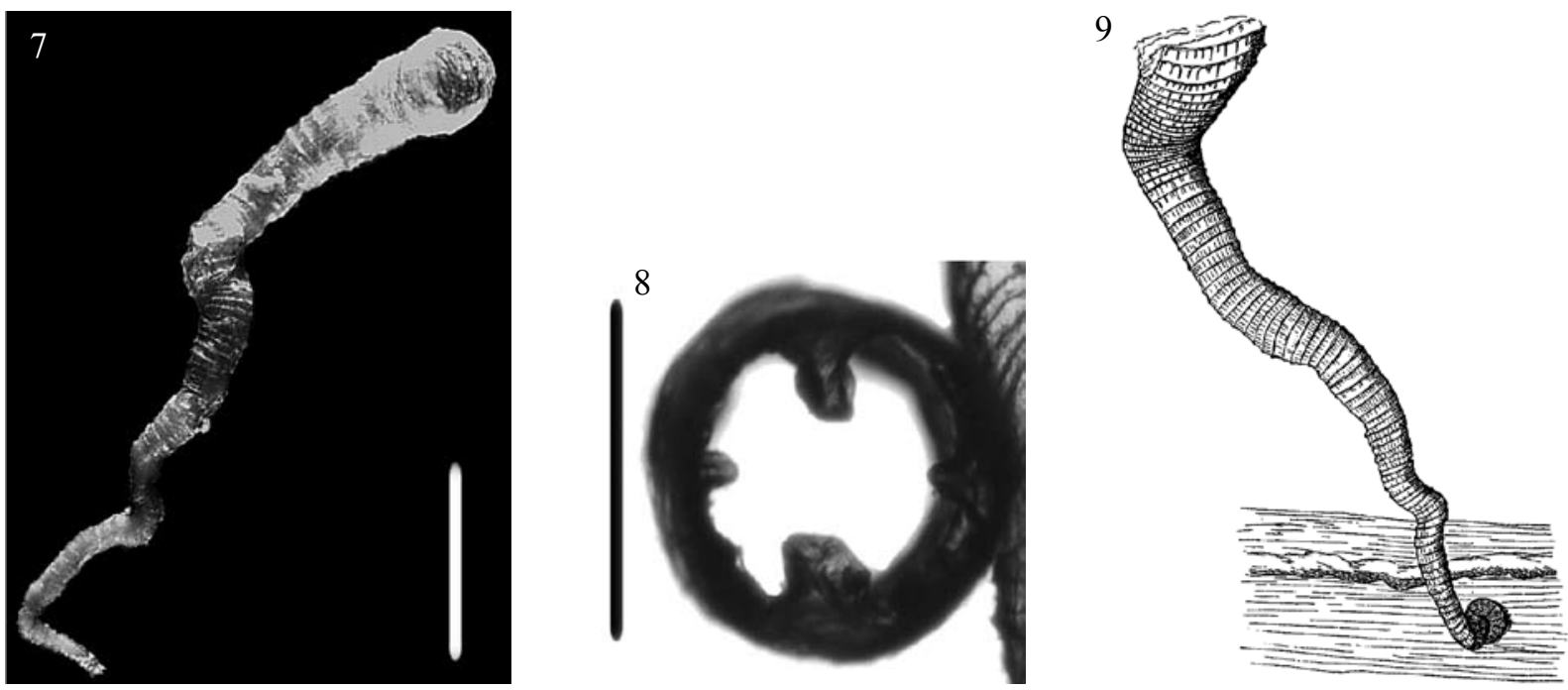

Fig. 7. Nausithoe striata (Vanhöffen, 1910) comb. nov., holotype (ZMB CNI 14816). Scale $=2 \mathrm{~mm}$.

Fig. 8. Nausithoe striata (Vanhöffen, 1910) comb. nov., distal whorl of internal cusps of the holotype (ZMB CNI 14816). Scale =1 mm.

Fig. 9. Nausithoe striata (Vanhöffen, 1910) comb. nov., reproduced from the original (Vanhöffen, 1910, fig. 6).

Description of the holotype. ZMB CNI 14816 (1 specimen) (Fig. 7). Solitary polyp (8.4 mm long), with light brown periderm tube, and small basal disc for attachment $(0.58 \mathrm{~mm})$. The diameter just above the basal disc is $0.14 \mathrm{~mm}$, at $2 \mathrm{~mm}$ height is $0.34 \mathrm{~mm}$, at $5 \mathrm{~mm}$ height is $0.64 \mathrm{~mm}$, and at the tube aperture is $0.96 \mathrm{~mm}$. Formquotient at $2 \mathrm{~mm}$ height 0.17 at 5 $\mathrm{mm}$ height 0.128 and at the aperture 0.114 . Tube surface with pattern of transverse rings ( $4-5$ rings $/ 0.4$ $\mathrm{mm}$ ) with longitudinal striations, characteristic of Nausithoidae. The tube has five whorls of internal cusps. The distal series has four cusps (two larger and 2 smaller ones) (Fig. 8). The outline of the internal cusps is higher than broad.

Type locality: Antarctic Ocean $\left(65^{\circ} \mathrm{S} 85^{\circ} \mathrm{E}\right), 2450$ $\mathrm{m}$ depth.

Collected by the "Deutsche Südpolar-Expedition" on 01.iii.1903.

Comments. Vanhöffen (1910: 280) described the solitary species Stephanoscyphus striatus, under the name Tubularia striata, based on material from 2450 $m$ depth in the Antarctic Ocean. His account provided no detailed information on meaningful taxonomic characters. Nevertheless, the drawing he provided (Vanhöffen, 1910: 280, fig. 6) (Fig. 9) clearly reveals that it is a coronate polyp. Although Vanhöffen assigned it to a hydrozoan genus Tubu- laria, he classified it as scyphozoan in the introduction of his paper by using the name Scyphistoma in reference to it. Data from our examination of the holotype (ZMB CNI 14816) are presented in Tab. 3. Vanhöffen (1910) did not mention internal structures within the tube. Leloup (1937) followed Thiel (1936) in regarding $S$. striatus as a senior synonym of $S$. bianconis, and noted that Lo Bianco (1903) had not mentioned the presence of any whorls of cusps in his material. Accordingly, in his key to species (Leloup, 1937: 69), he grouped S. striatus and Nausithoe racemosa (which has also no cusps) as species lacking cusps. But in our examination of Vanhöffen's type, however, we found 5 whorls having 4 cusps each (Fig. 8), with longitudinal attachment outlines (Tab. 3). A comparison with all other known solitary polyps of the genus Nausithoe (Tab. 3) shows clearly the differences in number of cusps per whorl. Besides that, no other coronate polyp is known from the Antarctic Ocean. Other characters of the tube (Formquotient) are similar to other species. With this finding in combination with the outer structure of the tube we can conclude that $S$. striatus should be referred to the genus Nausithoe Kölliker, 1853 (as Nausithoe striata comb. nov.) and to the family Nausithoidae.

With this new combination, out of $c a .20$ species of the family Nausithoidae, fourteen have a known polyp stage: Nausithoe aurea Silveira and Morandini, 
1997 (Southeastern Brazil, Atlantic Ocean); Nausithoe eumedusoides (Werner, 1974) (submarine caves, Mediterranean Sea); Nausithoe globifera Broch, 1914 (medusa: Northeastern Atlantic Ocean; polyp: Morocco coast, Atlantic Ocean); Nausithoe hagenbecki Jarms, 2001 (unknown locality, specimen from Hagenbeck Zoo Troparium, Hamburg); Nausithoe maculata Jarms, 1990 (Puerto Rico, Atlantic Ocean); Nausithoe marginata Kölliker, 1853 (Banyuls-surmer, Mediterranean Sea); Nausithoe planulophora (Werner, 1971) (submarine caves, Mediterranean Sea); Nausithoe punctata Kölliker, 1853 (supposed to be cosmopolitan); Nausithoe racemosa (Komai, 1935) (Japan, Pacific Ocean); Nausithoe sorbei Jarms, Tiemann and Prados, 2003 (Bay of Biscay, Azores, Atlantic Ocean); Nausithoe striata (Vanhöffen, 1910) comb. nov. (Antarctic Ocean); Nausithoe thieli Jarms, 1990 (Red Sea); Nausithoe werneri Jarms, 1990 (Morocco coast, Northeastern Atlantic Ocean); Thecoscyphus zibrowii Werner, 1984 (submarine caves, Mediterranean Sea).

The diagnosis of the family Nausithoidae is: Coronatae medusae with eight rhopalia (four perradial and four interradial); eight adradial tentacles; sixteen marginal lappets; without sac-like projections (pouches) on the subumbrella; solitary or colonial polyps (Stephanoscyphistoma-like) with external sculpturing with transversal rings somewhat distant from each other; outline of cusps, when present, from outside higher than broad. The diagnosis of the genus Nausithoe Kölliker, 1853 is: Nausithoidae medusae with eight adradial gonads, central stomach with four interradial septa which rang gastric filaments; solitary or colonial Nausithoidae polyps with varying number of internal cusps.

\section{General comments and Conclusions}

With our results on the morphology of the polyp stage we disagree with the suggestion of Mills et al. (1987) that the genus Atorella should be moved to the family Nausithoidae.

We believe that future examination of type specimens, or at least specimens from nearby the type localities, of the other Stephanoscyphistoma species will be a step towards increasing stability in the nomenclature and taxonomy of the coronates.

Stephanoscyphistoma sibogae (Leloup, 1937) is referred to the genus Atorella, as Atorella sibogae (Leloup, 1937) comb. nov.; and Stephanoscyphistoma striatus (Vanhöffen, 1910) is assigned to the genus Nausithoe, as Nausithoe striata (Vanhöffen, 1910) comb. nov. based on the morphology of the polyp stage.

\section{Acknowledgements}

This work was partly supported by Fundação de Amparo à Pesquisa do Estado de São Paulo (FAPESP 99/05374-7, PhD scholarship to the first author) with a scholarship to ACM from "Pós-Graduação, Área Zoologia, IBUSP”, Coordenação de Aperfeiçoamento de Pessoal de Nível Superior (CAPES/PROAP/Instituto de Biociências-USP),

Table 3. Comparative table with the measurements of different species of the genus Nausithoe Kölliker, 1853 with known solitary polyp stages ( N. aurea, N. eumedusoides, N. globifera, N. hagenbecki, N. maculata, N. marginata, N. planulophora, N. sorbei, N. striata comb. nov., N. thieli, N. werneri). For definitions of symbols, see Tab. 1; “*” = secondary teeth on cusps. Data from: Werner (1983), Jarms (1990; 1997; 2001), Jarms et al. (2002a; 2003), and Morandini and Silveira (2001).

\begin{tabular}{lllll}
\hline Species & $\mathrm{D} / \mathrm{L}_{5 \mathrm{~mm}}$ & Formquotient & cusps/whorl & Occurrence \\
\hline Nausithoe aurea & $0.07-0.14$ & $0.07-0.21$ & 16 & Brazil \\
Nausithoe eumedusoides & $0.132-0.164$ & $0.13-0.2$ & 1 & Mediterranean caves \\
Nausithoe globifera & 0.128 & 0.134 & 8 & N Atlantic (Morocco) \\
Nausithoe hagenbecki & 0.192 & 0.08 & 16 & $?$ \\
Nausithoe maculata & $0.112-0.148$ & $0.05-1.01$ & 16 & Caribbean \\
Nausithoe marginata & $0.08-0.112$ & $0.063-0.111$ & 8 & Mediterranean \\
Nausithoe planulophora & $(0.132)$ & $0.05-0.12$ & 8,16 & Mediterranean caves \\
Nausithoe sorbei & $0.11-0.21$ & $0.009-0.257$ & 1 & Bay of Biscay, Azores \\
Nausithoe striata (ZMB CNI 14816) & 0.128 & 0.114 & 4 & Antarctic Ocean \\
Nausithoe thieli & $0.056-0.072$ & $0.032-0.074$ & $2,4,8$ & Red Sea \\
Nausithoe werneri & $0.096-0.144$ & $0.069-0.113$ & $8 *$ & N Atlantic (Morocco)
\end{tabular}


Universität Hamburg, and Alexander von Humboldt Foundation. We would like to thank Drs C. Lüter (ZMB), R.W.M. van Soest and Mrs E. Beglinger (ZMA) for invaluable support during contact, Museum visits and loans. We also thank R. Walter (Universität Hamburg) for preparing specimens for SEM. Dr D.R. Calder (ROM) and two anonymous referees are acknowledged for suggestions to improve the manuscript.

\section{References}

Chapman DM, Werner B. 1972. Structure of a solitary and a colonial species of Stephanoscyphus (Scyphozoa, Coronatae) with observations on periderm repair. Helgoländer wiss. Meeresunters. 23: 393-421.

Cornelius PFS. 1997. Keys to the genera of cubomedusae and scyphomedusae (Cnidaria). In: den Hartog JC, ed. Proceedings of the 6th International Conference on Coelenterate Biology, 1995, Nationaal Natuurhistorisch Museum, Leiden: 109-122.

Jarms G. 1990. Neubeschreibung dreier Arten der Gattung Nausithoe (Coronata, Scyphozoa) sowie Wiederbeschreibung der Art Nausithoe marginata Kölliker, 1853. Mitt. hamb. zool. Mus. Inst. 87: 7-39.

Jarms G. 1991. Taxonomic characters from the polyp tubes of coronate medusae (Scyphozoa, Coronatae). Hydrobiologia, 216-217: 463-470.

Jarms G. 1997. The polyps of Coronatae (Scyphozoa), a review and some new results. In: den Hartog JC, ed. Proceedings of the 6th International Conference on Coelenterate Biology, 1995, Nationaal Natuurhistorisch Museum, Leiden: 271-278.

Jarms G. 2001. The life cycle of Nausithoe hagenbecki sp. nov. (Scyphozoa, Coronatae). Mitt. hamb. zool. Mus. Inst. 98: $13-22$.

Jarms G, Morandini AC, Silveira FL da. 2002a. Polyps of the families Atorellidae and Nausithoidae (Scyphozoa: Coronatae) new to the Brazilian fauna. Biota Neotr. 2(1): 11p. [available at http://www.biotaneotropica.org.br/v2n1/en/abstract? article+BN01202012002]

Jarms G, Morandini AC, Silveira FL da. 2002b. Cultivation of polyps and medusae of Coronatae (Cnidaria, Scyphozoa) with a brief review of important characters. Helgol. Mar. Res. 56 (3): 203-210.

Jarms G, Tiemann H, Prados AA. 2003. A new bathybenthic coronate polyp, Nausithoe sorbei sp. nov. (Scyphozoa, Coronatae), from the Bay of Biscay and off Azores. Mitt. hamb. zool. Mus. Inst. 100: 1-11.

ICZN, 1999. International Code of Zoological Nomenclature, $4^{\text {th }}$ edition. ITZN, London, 1-306.

Kawaguti S, Matsuno A. 1981. A new species of the Coronatae, Scyphozoa, from the Japan Sea; Atorella japonica n.sp. Bull. Kawasaki Paramed. Coll. 1: 15-21.

Kirkpatrick R. 1890. Report upon the Hydrozoa and Polyzoa collected by P.W. Bassett-Smith, Esq., Surgeon R.N., during the Survey of the Tizard and Macclesfield Banks, in the Chi- na Sea, by H.M.S. 'Ramler', Commander W.U. Moore. Ann. \& Mag. N. Hist., ser. 6 5: 11-24 [Pls III-IV].

Kramp PL. 1951. Hydrozoa and Scyphozoa. Rep. Swedish Deep-sea Exped., Zool. 2 (10): 121-127.

Kramp PL. 1955. A revision of Ernst Haeckel's determinations of a collection of medusae belonging to the Zoological Museum of Copenhagen. Deep-Sea Res. 3 (Suppl.): 149-168.

Kramp PL. 1959. Stephanoscyphus (Scyphozoa). Galathea Rep. 1: $173-187$.

Kraus O. 2000. Internationale Regeln für die Zoologische Nomenklatur. 4. Auflage. Abh. naturwiss. Ver. Hamburg (NF) 34. Goecke und Evers, Keltern-Weiler.

Leloup E. 1937. Hydropolypes et scyphopolypes recueillis par C. Dawydoff sur les côtes de l'Indochine française. Mém. Mus. R. d'hist. nat. Belgique, Sér. 2 12: 1-73.

Lo Bianco S. 1903. Le pesche abissali eseguite da F. A. Krupp col Yacht Puritan nelle adiacenze di Capri ed in altre località del Mediterraneo. Mitt. zool. sta. Neapel 16: 109-281.

Morandini AC, Silveira FL da. 2001. New observations and new record of Nausithoe aurea (Scyphozoa, Coronatae). Pap. Av. Zool. 41(27): 519-527.

Naumov DV. 1959. [Generic classification of polypoid generations of Coronomedusae]. Dokl. Akad. Nauk SSSR Biol. Sec. 126: 582-584 [in Russian].

Russell FS. 1970. The medusae of the British Isles II. Pelagic Scyphozoa with a supplement to the first volume on hydromedusae. Cambridge University Press, London: 1-284.

Stechow E. 1925. Hydroiden der Deutschen Tiefsee-Expedition. Deutsche Tiefsee-Exped. 17 (3): 383-546.

Thiel ME. 1936. Ordung Coronatae. In: Bronns, H.G. Klassen und Ordnungen des Tierreichs. Zweiter Band, II. Abteilung, 2 buch Scyphomedusae, Akademische Verlagsgesellschaft m.b.H., Leipzig: 308-471.

Vanhöffen E. 1910. Die Hydroiden der Deutschen SüdpolarExpedition 1901-1903. Deutsche Südpolar-Exped., Zool. 3 11: $269-340$.

Werner B. 1967. Morphologie, systematic und Lebensgeschichte von Stephanoscyphus (Scyphozoa, Coronatae), sowie seine Bedeutung für die Evolution der Scyphozoa. Zool. Anz. Suppl. 30: 297-319.

Werner B. 1971. Stephanoscyphus planulophorus n. spec., eine neuer Scyphopolyp mit einem neuen Entwicklungsmodus. Helgoländer wiss. Meeresunters. 22: 120-140.

Werner B. 1973. New investigations on systematics and evolution of the class Scyphozoa and the phylum Cnidaria. Publs. Seto mar. biol. Lab. 20: 35-61.

Werner B. 1974. Stephanoscyphus eumedusoides n. spec. (Scyphozoa, Coronatae), ein Höhlenpolyp mit einem neuen Entwicklungsmodus. Helgoländer wiss. Meeresunters. 26: 434463.

Werner B. 1979. Coloniality in the Scyphozoa: Cnidaria. In: Larwood, G. and B.R. Rosen (eds.). Biology and systematics of colonial organisms. Academic Press, London: 81-103.

Werner B. 1983. Weitere Untersuchungen zur Morphologie, Verbreitung und Ökologie von Stephanoscyphus planulophorus (Scyphozoa, Coronata). Helgoländer wiss. Meeresunters. 36: 119-135.

Received: 3 March 2004

Acccepted: 8 September 2005 
